\title{
Microstructure and mechanical properties of an ultrafine Ti-Si-Nb alloy
}

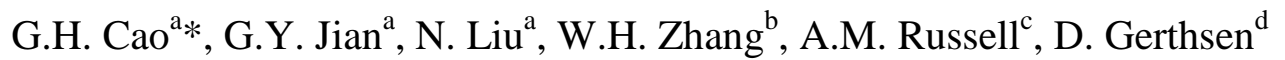 \\ ${ }^{a}$ Department of Materials Engineering and State Key Laboratory of Advanced Special Steels, \\ Shanghai University, 149 Yanchang Road, Shanghai 200072, PR China \\ ${ }^{\mathrm{b}}$ Department of Mechanical Engineering, Changzhou Technician College Jiangsu Province, 8 \\ Nenjiang Road, Changzhou 213032, P.R. China \\ ${ }^{\mathrm{c}}$ Division of Materials Science and Engineering, Ames Laboratory of the U.S.D.O.E., and \\ Department of Materials Science and Engineering, Iowa State University, Ames, IA 50011-2300, \\ USA \\ ${ }^{\mathrm{d}}$ Laboratorium für Elektronenmikroskopie, Karlsruher Institut für Technologie, D-76128 \\ Karlsruhe, Germany
}

\begin{abstract}
Nb-modified ultrafine Ti-Si eutectic alloy was made by cold crucible levitation melting, tested in compression at room temperature, and characterized by electron microscopy. Compression tests of $\left(\mathrm{Ti}_{86.5} \mathrm{Si}_{13.5}\right)_{97} \mathrm{Nb}_{3}$ specimens measured an ultimate compressive strength of $1180 \mathrm{MPa}$ and a compressive plastic strain of $12 \%$, both of which are higher than in eutectic $\mathrm{Ti}_{86.5} \mathrm{Si}_{13.5}$ alloy. Electron microscopy showed that the Ti-Si-Nb alloy had a bimodal microstructure with micrometer-scale primary $\alpha$-Ti dendrites distributed in an ultrafine eutectic $\left(\alpha-\mathrm{Ti}+\mathrm{Ti}_{5} \mathrm{Si}_{3}\right)$ matrix. The enhanced ductility is attributed to the morphology of the phase constituents and to the larger lattice mismatches between $\alpha-\mathrm{Ti}$ and $\mathrm{Ti}_{5} \mathrm{Si}_{3}$ phases caused by the $\mathrm{Nb}$ addition. The crystallographic orientation relationship of $\mathrm{Ti}_{5} \mathrm{Si}_{3}$ with $\alpha-\mathrm{Ti}$ is $\left(1 \overline{100)}[\overline{1} \overline{1} 26] \mathrm{Ti}_{5} \mathrm{Si}_{3} \|\right.$ $(01 \overline{1} 1)[5 \overline{1} \overline{4} \overline{3}] \alpha-\mathrm{Ti}$.
\end{abstract}

Keywords: Alloys; Electron microscopy; Mechanical testing; Ductility;

Microstructure

\footnotetext{
* Corresponding author. Tel./fax: +86 2156337244.

E-mail address: ghcao@ shu.edu.cn (G.H. Cao).
} 


\section{Introduction}

Titanium alloys have relatively low density, high tensile strength and toughness, and good elevated-temperature oxidation resistance and strength. This combination of properties makes titanium alloys widely useful for aerospace, medical, structural, and chemical processing applications [1,2]. Ultrafine grained (ufg) and nanocrystalline (nc) Ti-based alloys would provide much greater strength than their coarse-grained counterparts, as indicated by the well-known Hall-Petch relation. Reducing the grain size will cause the material to become stronger [3]; however, ultrafine-grain (ufg) and nanocrystalline (nc) materials typically have low ductility and fracture toughness, making them vulnerable to catastrophic failure. This limits their engineering usefulness as structural materials [4]. The ductility limitations of ufg and nc materials have been attributed to artifacts from sample preparation, force instability in tension, and crack nucleation or propagation instability [5].

Improving the ambient temperature ductility of ufg and nc materials has been an important subject in the development of advanced structural materials. Various strategies have been employed to improve the ductility of nanostructured metals and alloys, including bimodal (or multi-modal) grain size distributions [3,6]. Wang et al. reported that an unusually large strain $(\sim 65 \%)$ and high yield strength $(\sim 400 \mathrm{MPa})$ were achieved by cold rolling $\mathrm{Cu}$ to create a bimodal grain size distribution with micrometer-sized grains embedded inside a matrix of nanocrystalline grains [7]. Other ductilizing approaches include materials with nano-twins, using phase transformation and twinning-induced ductility to achieve high strength, ductility and conductivity $[3,6,8-10]$

Silicon is an important alloying element in Ti-based alloys destined for elevatedtemperature applications. It is used extensively as an effective strengthening agent in 
solid solution. In addition, the precipitation of silicide compounds (e.g., $\mathrm{Ti}_{5} \mathrm{Si}_{3}$ ) was found to provide a useful contribution to dispersion strengthening and improved microstructural stability at elevated temperatures [11,12]. Si also improves creep resistance of TiAl-based alloys by forming $\mathrm{Ti}_{5} \mathrm{Si}_{3}$ silicide that pins dislocations [13]. Significant research efforts on transition-metal (TM) silicides with the 5:3 stoichiometry $\left(\mathrm{TM}_{5} \mathrm{Si}_{3}\right)$ have been conducted to examine their synthesis $[14,15]$, mechanical properties [16,17], deformation [18], thermal properties and oxidation behavior [19,20]. However, information about the microstructure and mechanical properties for eutectic Ti-Si alloys is still limited. $\mathrm{Nb}$ is a $\beta$-Ti stabilizer, and the Ti$\mathrm{Nb}$ binary phase diagram reveals that $\mathrm{Ti}$ and $\mathrm{Nb}$ can form solid solutions at all compositions at elevated temperatures [21]. Thus, it is expected that $\mathrm{Nb}$ addition might improve the ductility of the eutectic Ti-Si alloys by changing the microstructural morphology.

In the present research, we report on the relation between microstructure and mechanical behavior of Ti-Si eutectic alloys modified by $\mathrm{Nb}$ addition. The as-cast $\mathrm{Nb}$ modified Ti-Si eutectic alloy having bimodal structure shows a plastic strain of $12 \%$ while preserving an ultimate strength of $1180 \mathrm{MPa}$. We pay special attention to the correlation between the microstructures and mechanical properties. It is hoped that this study will improve understanding of ufg and nc materials by providing a better understanding of methods to produce high-performance ufg and nc structural materials via microstructural manipulation.

\section{Experimental procedure}

Ingots with a nominal composition (at.\%) of $\mathrm{Ti}_{86.5} \mathrm{Si}_{13.5}$ and $\left(\mathrm{Ti}_{86.5} \mathrm{Si}_{13.5}\right)_{97} \mathrm{Nb}_{3}$ were fabricated from high-purity $(99.99 \%) \mathrm{Ti}, \mathrm{Si}$, and $\mathrm{Nb}$ metals by cold crucible levitation melting under argon atmosphere on a water-cooled $\mathrm{Cu}$ crucible. The melted 
ingots were flipped and re-melted four times in order to minimize composition variation within the specimens. The phase constituents of the alloys were characterized by a D/MAX-3C X-ray diffractometer using $\mathrm{Cu} \mathrm{K}_{\alpha 1}$ radiation $(\lambda=$ $0.1541 \mathrm{~nm}$ ). Compression specimens $3 \mathrm{~mm}$ in diameter and $6 \mathrm{~mm}$ long were cut by electrical-discharge machining (EDM). The compression tests were carried out at a constant strain rate of $1 \times 10^{-3} \mathrm{~s}^{-1}$ in a CMT5305 electronic universal testing machine at room temperature. Metallographic structure of the alloys and the fracture surfaces of compression specimens were examined using a scanning electron microscope (SEM, JSM-7001) equipped with energy-dispersive X-ray spectroscopy (EDXS). Transmission electron microscope (TEM) specimens were cut by EDM from the ascast ingots, ground and thinned by electropolishing in a solution of $65 \mathrm{vol} . \%$ methanol, $30 \mathrm{vol} . \%$ butanol, and $5 \mathrm{vol} . \%$ perchloric acid at a voltage of $30 \mathrm{~V}$ and temperatures between $-20^{\circ}$ and $-30^{\circ} \mathrm{C}$. TEM bright field (BF) imaging and selected area electron diffraction (SAED) were performed in a Philips CM 200 ST microscope with a field emission gun operating at an acceleration voltage of $200 \mathrm{kV}$.

\section{Results and discussion}

Fig. 1 shows the X-ray diffractograms of the $\mathrm{Ti}_{86.5} \mathrm{Si}_{13.5}$ and $\left(\mathrm{Ti}_{86.5} \mathrm{Si}_{13.5}\right)_{97} \mathrm{Nb}_{3}$ alloys. X-ray diffraction (XRD) patterns reveal that both alloys were found to consist of the hexagonal $\alpha$-Ti (space group: $\mathrm{P}_{3} / \mathrm{mmc}, \mathrm{A} 3$ structure) solid solution and the ordered hexagonal $\mathrm{Ti}_{5} \mathrm{Si}_{3}$ (space group: $\mathrm{P} 6_{3} / \mathrm{mcm}, \mathrm{D} 8_{8}$ structure) intermetallic compound. Addition of 3 at.\% $\mathrm{Nb}$ does not change the phase constitution of $\left(\mathrm{Ti}_{86.5} \mathrm{Si}_{13.5}\right)_{97} \mathrm{Nb}_{3}$ alloy. The lattice parameters of the $\alpha$-Ti solid solution of the $\mathrm{Ti}_{86.5} \mathrm{Si}_{13.5}$ and $\left(\mathrm{Ti}_{86.5} \mathrm{Si}_{13.5}\right)_{97} \mathrm{Nb}_{3}$ alloys are $a=0.2965 \mathrm{~nm}, c=0.4705 \mathrm{~nm}$ and $a=$ $0.2968 \mathrm{~nm}, c=0.4716 \mathrm{~nm}$, respectively, which is larger than that of pure $\alpha-\operatorname{Ti}(a=$ $0.2944 \mathrm{~nm}, c=0.4678 \mathrm{~nm}$ ) due to dissolution with $\mathrm{Si}$ and $\mathrm{Nb}$ [22]. The chemical 


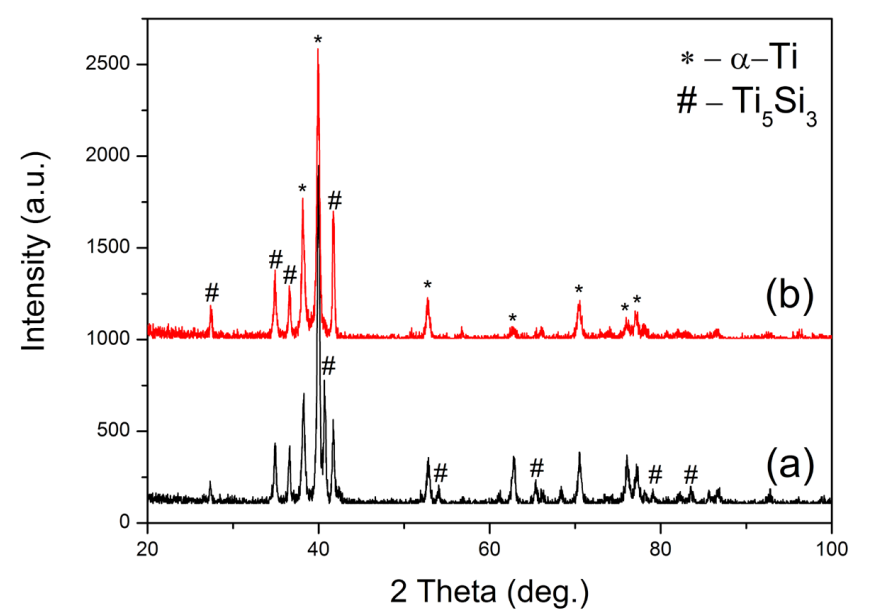

Fig. 1. XRD diffractograms of (a) $\mathrm{Ti}_{86.5} \mathrm{Si}_{13.5}$ and (b) $\left(\mathrm{Ti}_{86.5} \mathrm{Si}_{13.5}\right)_{97} \mathrm{Nb}_{3}$ alloys.

composition of the $\alpha$-Ti and $\mathrm{Ti}_{5} \mathrm{Si}_{3}$ phases in $\mathrm{Ti}_{86.5} \mathrm{Si}_{13.5}$ and $\left(\mathrm{Ti}_{86.5} \mathrm{Si}_{13.5}\right)_{97} \mathrm{Nb}_{3}$ alloys measured by EDXS is shown in Table 1. The lattice parameters for $\mathrm{Ti}_{5} \mathrm{Si}_{3}$ in $\mathrm{Ti}_{86.5} \mathrm{Si}_{13.5}$ alloy are determined to be $a=0.7492 \mathrm{~nm}$, and $c=0.5136 \mathrm{~nm}$. Nb addition results in lattice expansion for both the $a$ - and $c$-directions compared to the $\operatorname{Ti}_{86.5} \mathrm{Si}_{13.5}$ alloy, the lattice parameters for $\mathrm{Ti}_{5} \mathrm{Si}_{3}$ in $\left(\mathrm{Ti}_{86.5} \mathrm{Si}_{13.5}\right)_{97} \mathrm{Nb}_{3}$ alloy are $a=0.7498 \mathrm{~nm}$ and $c=0.5141 \mathrm{~nm}$. From the detailed analysis of these data, it is observed that $\mathrm{Nb}$ addition to $\mathrm{Ti}_{86.5} \mathrm{Si}_{13.5}$ alloy causes larger lattice mismatch between the $\mathrm{A} 3 \alpha$-Ti and $\mathrm{D} 8_{8} \mathrm{Ti}_{5} \mathrm{Si}_{3}$ phases.

\section{Table 1}

EDXS of the chemical composition (at.\%) of the $\alpha$-Ti and $\mathrm{Ti}_{5} \mathrm{Si}_{3}$ phases.

\begin{tabular}{lccccccccc}
\hline Sample & \multicolumn{4}{c}{ Primary $\alpha$-Ti dendrite } & \multicolumn{3}{c}{$\alpha$-Ti in eutectic matrix } & \multicolumn{3}{c}{$\mathrm{Ti}_{5} \mathrm{Si}_{3}$ in eutectic matrix } \\
& $\mathrm{Ti}$ & $\mathrm{Si}$ & $\mathrm{Nb}$ & $\mathrm{Ti}$ & $\mathrm{Si}$ & $\mathrm{Nb}$ & $\mathrm{Ti}$ & $\mathrm{Si}$ & $\mathrm{Nb}$ \\
\hline $\mathrm{Ti}_{86.5} \mathrm{Si}_{13.5}$ & - & - & - & $84-89$ & $11-16$ & - & $65-78$ & $22-35$ & - \\
$\left(\mathrm{Ti}_{86.5} \mathrm{Si}_{13.5}\right)_{97} \mathrm{Nb}_{3}$ & $91-94$ & $2-4$ & $4-5$ & $78-87$ & $11-18$ & $2-4$ & $65-69$ & $27-33$ & $2-4$ \\
\hline
\end{tabular}

Fig. 2a and $\mathrm{b}$ (higher magnification of (a)) present SEM backscattered electron (BSE) images of the eutectic $\mathrm{Ti}_{86.5} \mathrm{Si}_{13.5}$ alloy, displaying a typical rod-like eutectic structure with a rod spacing of $150-600 \mathrm{~nm}$ with the $\mathrm{Ti}_{5} \mathrm{Si}_{3}$ rods being $150-500 \mathrm{~nm}$ in diameter. EDXS analysis indicated that the brighter rod-like phase is $\mathrm{Ti}_{5} \mathrm{Si}_{3}$, and the dark contrast area is $\alpha$-Ti. A SEM BSE micrograph shown in Fig. 2 c reveals a bimodal phase size distribution with primary $\alpha$-Ti dendrites embedded in an ultrafine 
matrix for the $\left(\mathrm{Ti}_{86.5} \mathrm{Si}_{13.5}\right)_{97} \mathrm{Nb}_{3}$ alloy. With higher magnification, Fig. $2 \mathrm{~d}$, it is seen that the diameter of the rod-like $\mathrm{Ti}_{5} \mathrm{Si}_{3}$ phase is about $150-700 \mathrm{~nm}$. The rod spacing of the eutectic structure in the $\left(\mathrm{Ti}_{86.5} \mathrm{Si}_{13.5}\right)_{97} \mathrm{Nb}_{3}$ alloy $(100-500 \mathrm{~nm})$ is finer than that in the $\mathrm{Ti}_{86.5} \mathrm{Si}_{13.5}$ alloy. EDXS measurements shown in Table 1 reveal that the solubility of $\mathrm{Si}$ in $\alpha-\mathrm{Ti}$ in the Ti-Si eutectic alloy is $11-16$ at.\%, indicating that the $\alpha$-Ti is a solid solution. Si content in the $\mathrm{Ti}_{5} \mathrm{Si}_{3}$ phase in the Ti-Si eutectic alloy is 22-35 at.\%, which is lower than the range shown in the binary Ti-Si phase diagram [21]. The solubility of $\mathrm{Nb}$ in primary $\alpha$-Ti dendrites, eutectic $\alpha-\mathrm{Ti}$, and $\mathrm{Ti}_{5} \mathrm{Si}_{3}$ phases is $2-5$ at.\%. The $\mathrm{Si}$ content in eutectic $\alpha$-Ti and $\mathrm{Ti}_{5} \mathrm{Si}_{3}$ phases in $\left(\mathrm{Ti}_{86.5} \mathrm{Si}_{13.5}\right)_{97} \mathrm{Nb}_{3}$ shows a similar value in comparison with the $\mathrm{Ti}_{86.5} \mathrm{Si}_{13.5}$ alloy. Therefore, it is clear that $\mathrm{Nb}$ acts as a substitutional impurity on Ti sites in the $\alpha$-Ti solid solution and $\mathrm{Ti}_{5} \mathrm{Si}_{3}$ phase.
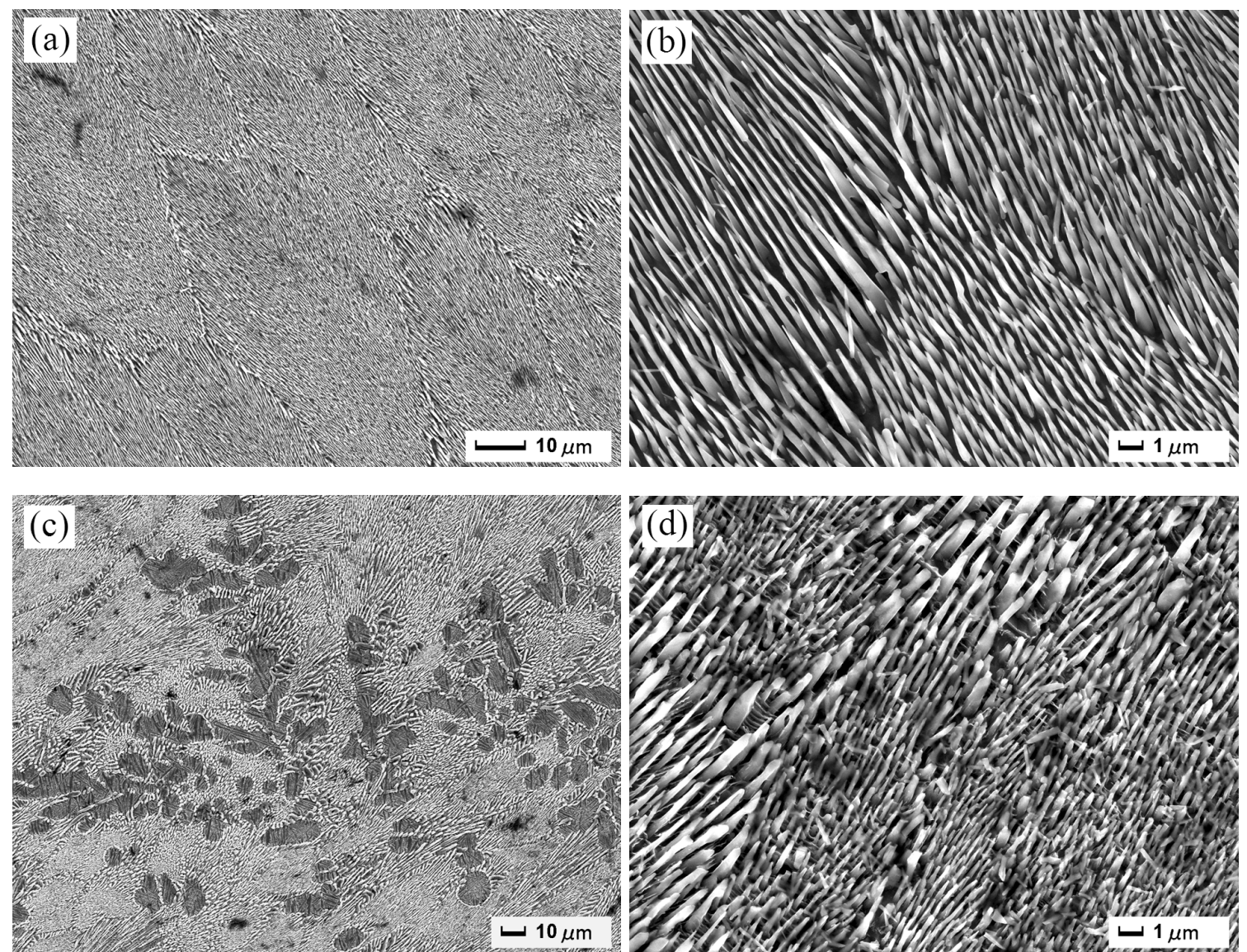

Fig. 2. SEM BSE micrographs of (a) $\mathrm{Ti}_{86.5} \mathrm{Si}_{13.5}$, (c) $\left(\mathrm{Ti}_{86.5} \mathrm{Si}_{13.5}\right)_{97} \mathrm{Nb}_{3}$ alloys, (b) and (d) high magnification of (a) and (c). 
Stress-strain curves at room temperature for $\mathrm{Ti}_{86.5} \mathrm{Si}_{13.5}$ and $\left(\mathrm{Ti}_{86.5} \mathrm{Si}_{13.5}\right)_{97} \mathrm{Nb}_{3}$ alloys are shown in Fig. 3. The eutectic $\mathrm{Ti}_{86.5} \mathrm{Si}_{13.5}$ alloy has an ultimate strength of $1078 \mathrm{MPa}$ and a plastic strain of $10 \%$ (fracture strain: $12 \%$ ) in compression. The $\left(\mathrm{Ti}_{86.5} \mathrm{Si}_{13.5}\right)_{97} \mathrm{Nb}_{3}$ alloy displayed a substantially higher plastic strain of $12 \%$ (fracture strain: $14 \%$ ) and an ultimate strength of $1180 \mathrm{MPa}$. Therefore, the $\mathrm{Nb}$ addition in $\left(\mathrm{Ti}_{86.5} \mathrm{Si}_{13.5}\right)_{97} \mathrm{Nb}_{3}$ alloy significantly improves compressive room temperature ductility and ultimate strength vis-à-vis $\mathrm{Ti}_{86.5} \mathrm{Si}_{13.5}$. Fig. 4 shows $\mathrm{SEM}$ secondary electron (SE) images of the fracture surface of the $\mathrm{Ti}_{86.5} \mathrm{Si}_{13.5}$ and $\left(\mathrm{Ti}_{86.5} \mathrm{Si}_{13.5}\right)_{97} \mathrm{Nb}_{3}$ alloys after compression at room temperature. The pull out of the $\mathrm{Ti}_{5} \mathrm{Si}_{3}$ phases and the relatively flat-faceted fracture surface (Fig. 4a and b (higher magnification of (a)) indicate little plastic flow before failure in eutectic $\mathrm{Ti}_{86.5} \mathrm{Si}_{13.5}$ alloy. The final fracture will take place by cleavage. The fracture surface (Fig. 4c and d (higher magnification of (c)) of $\left(\mathrm{Ti}_{86.5} \mathrm{Si}_{13.5}\right)_{97} \mathrm{Nb}_{3}$ alloy shows an apparent change in fractographic appearance. The dimple-like pattern in the fracture surface is evidence of ductile deformation.

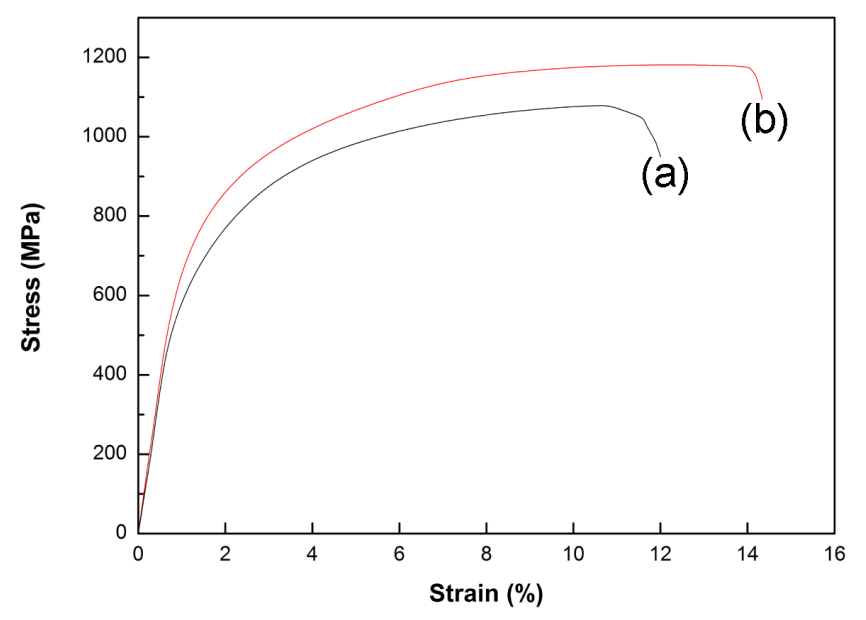

Fig. 3. Stress-strain curves of (a) $\mathrm{Ti}_{86.5} \mathrm{Si}_{13.5}$ and (b) $\left(\mathrm{Ti}_{86.5} \mathrm{Si}_{13.5}\right)_{97} \mathrm{Nb}_{3}$ alloys. 

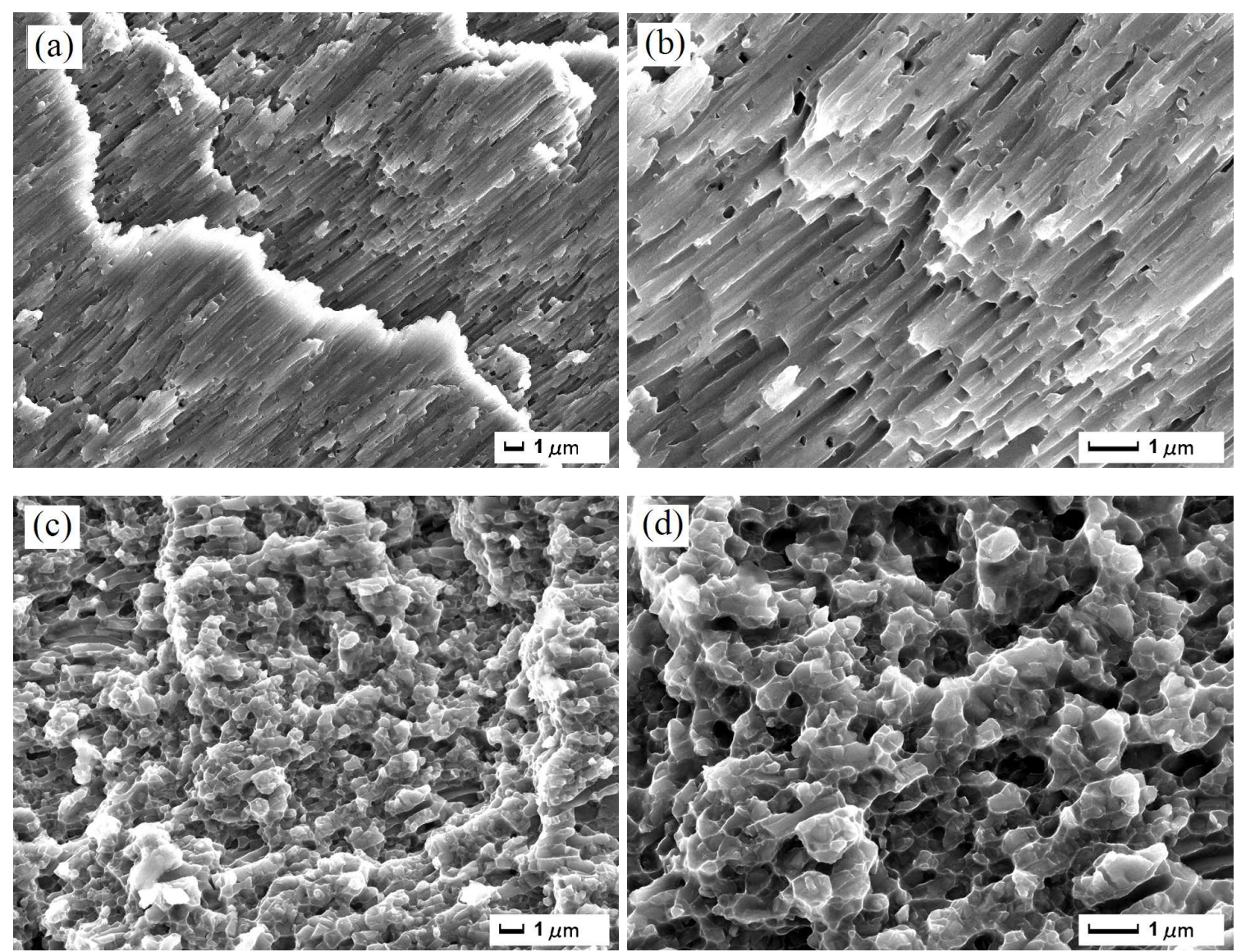

Fig. 4. SEM SE images of the fracture surfaces of (a) $\mathrm{Ti}_{86.5} \mathrm{Si}_{13.5}$, (c) $\left(\mathrm{Ti}_{86.5} \mathrm{Si}_{13.5}\right)_{97} \mathrm{Nb}_{3}$ alloys, (b) and (d) high magnification of (a) and (c).

Fig. 5a is a TEM BF image of the eutectic $\mathrm{Ti}_{86.5} \mathrm{Si}_{13.5}$ alloy showing a typical rodlike structure. The rod spacing and the diameter of the $\mathrm{Ti}_{5} \mathrm{Si}_{3}$ rods are measured to be about $100-400 \mathrm{~nm}$ and $100-300 \mathrm{~nm}$, respectively. Fig. $5 \mathrm{~b}$ is the SAED pattern of the $\mathrm{Ti}_{5} \mathrm{Si}_{3}$ rod in Fig. 5a along the [ $\left.\overline{1} \overline{1} 26\right]$ zone axis. Indexing showed that the $\mathrm{Ti}_{5} \mathrm{Si}_{3}$ phase has a D8 8 structure with lattice parameter $a=0.749 \mathrm{~nm}$, and $c=0.514 \mathrm{~nm}$. Fig. $5 c$ is the SAED pattern of the $\alpha$-Ti in Fig. 5a along the [5 $\overline{1} \overline{4} \overline{3}$ ] zone axis; from this we deduced that the hexagonal $\alpha$-Ti structure has lattice parameters of $a=0.297 \mathrm{~nm}$ and $c=0.472 \mathrm{~nm}$. Fig. $5 \mathrm{~d}$ shows the SAED patterns of $\mathrm{Ti}_{5} \mathrm{Si}_{3}$ and $\alpha-\mathrm{Ti}$, yielding the orientation relationship (1 $\overline{1} 00)[\overline{1} \overline{1} 26] \mathrm{Ti}_{5} \mathrm{Si}_{3} \|(01 \overline{1})[5 \overline{1} \overline{4} \overline{3}] \alpha$-Ti. Electron diffraction reveals that the $\mathrm{Ti}_{5} \mathrm{Si}_{3}$ and $\alpha$-Ti phases in the $\left(\mathrm{Ti}_{86.5} \mathrm{Si}_{13.5}\right)_{97} \mathrm{Nb}_{3}$ alloy have 
the same SAED patterns as those of Fig. $5 b$ and c. The crystallographic orientation relationship of the $\mathrm{Ti}_{5} \mathrm{Si}_{3}$ and $\alpha$-Ti phases observed in the $\left(\mathrm{Ti}_{86.5} \mathrm{Si}_{13.5}\right)_{97} \mathrm{Nb}_{3}$ alloy is in good agreement with that obtained from the SAED patterns of Fig. 5d in the eutectic $\mathrm{Ti}_{86.5} \mathrm{Si}_{13.5}$ alloy.
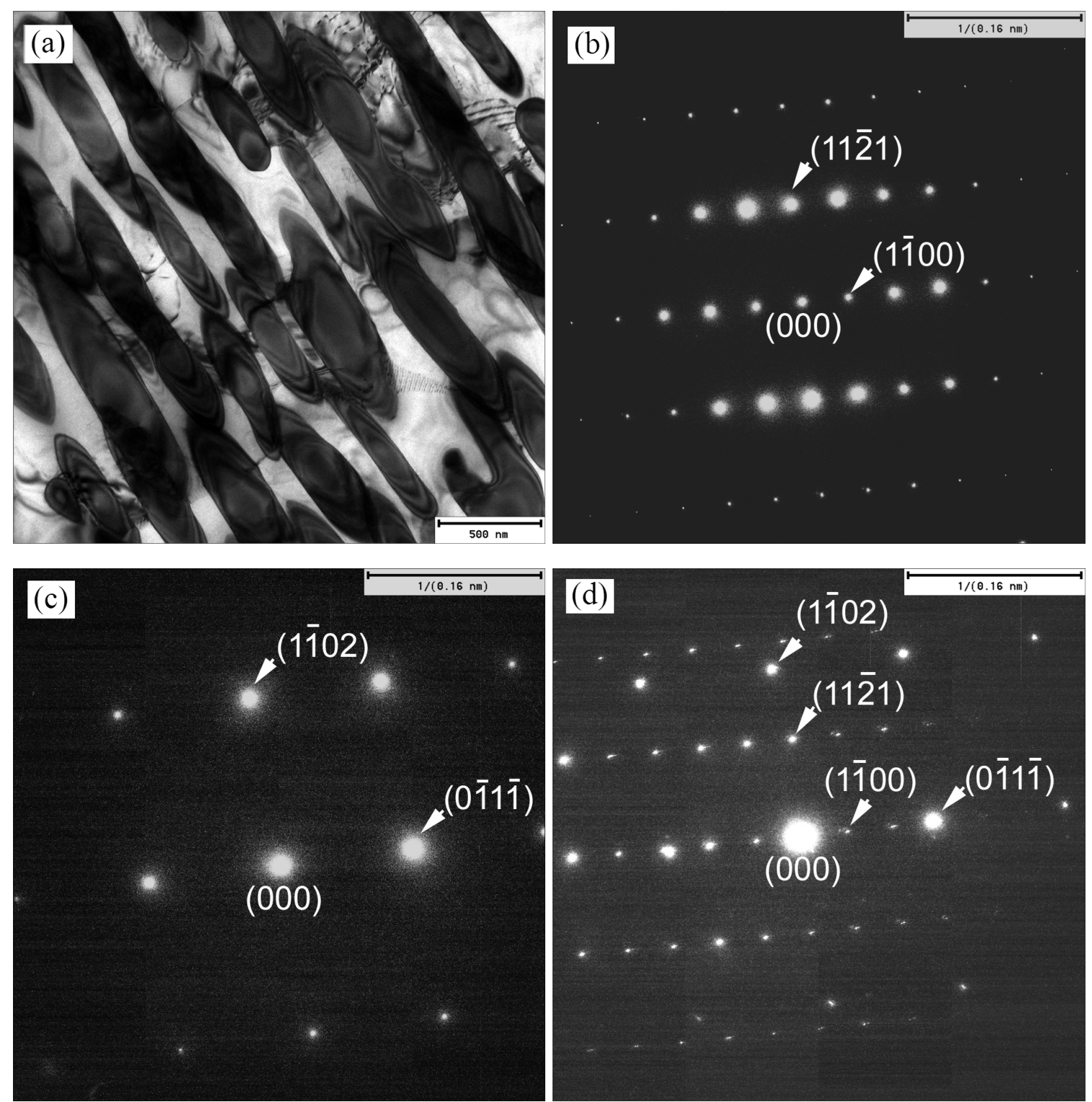

Fig. 5. (a) TEM BF image of (a) $\mathrm{Ti}_{86.5} \mathrm{Si}_{13.5}$ alloy, $\mathrm{SAED}$ patterns of (b) $\mathrm{D} 8_{8} \mathrm{Ti}_{5} \mathrm{Si}_{3}$ and (c) A3 $\alpha$-Ti phases corresponding to [ $\overline{1} \overline{1} 26] \mathrm{Ti}_{5} \mathrm{Si}_{3}$ and [5 $\left.\overline{1} \overline{4} \overline{3}\right] \alpha$-Ti zone axes, and (d) composite electron diffraction patterns of $\alpha-\mathrm{Ti}$ and $\mathrm{Ti}_{5} \mathrm{Si}_{3}$ showing their orientation relationship. 
$\mathrm{Si}$ and $\mathrm{Nb}$ are known as $\alpha$ - and $\beta$-Ti stabilizer elements, respectively.

Dobromyslov et al. [23] reported that the minimum concentration limit of the alloying metal $\mathrm{Nb}$ necessary for the complete stabilization of the $\beta$-Ti in binary $\mathrm{Ti}-\mathrm{Nb}$ alloy is about 23 at.\%. Therefore, there is only $\alpha-\mathrm{Ti}(\mathrm{Si}, \mathrm{Nb})$ phase formation with the addition of 3 at.\% $\mathrm{Nb}$ in the $\left(\mathrm{Ti}_{86.5} \mathrm{Si}_{13.5}\right)_{97} \mathrm{Nb}_{3}$ alloy, which has been confirmed by XRD and SEM results shown in Fig. 1 and 2. The lattice parameters of the $\alpha$-Ti in the eutectic $\mathrm{Ti}_{86.5} \mathrm{Si}_{13.5}$ and $\left(\mathrm{Ti}_{86.5} \mathrm{Si}_{13.5}\right)_{97} \mathrm{Nb}_{3}$ alloys are larger than those of pure $\alpha$-Ti ( $a=0.2944$ $\mathrm{nm}, c=0.4678 \mathrm{~nm}$ ) due to dissolution of $\mathrm{Si}$ and $\mathrm{Nb}$ ( Table 1). XRD analysis indicates that $\mathrm{Nb}$ addition leads to the expansion of the lattice parameters in both the $a$ - and $c$-directions for the $\mathrm{Ti}_{5} \mathrm{Si}_{3}$ phase. The lattice parameters of the $\mathrm{Ti}_{5} \mathrm{Si}_{3}$ phase in the $\mathrm{Nb}$-modified $\left(\mathrm{Ti}_{86.5} \mathrm{Si}_{13.5}\right)_{97} \mathrm{Nb}_{3}$ alloy were larger than those in the eutectic $\mathrm{Ti}_{86.5} \mathrm{Si}_{13.5}$ alloy due to the $\mathrm{Nb}$ substitution for part of the $\mathrm{Ti}$ in $\mathrm{Ti}_{5} \mathrm{Si}_{3}$ crystals, as shown in Table 1. The observed maximum amounts of $\mathrm{Nb}$ and $\mathrm{Cr}$ dissolved in $\mathrm{Ti}_{5} \mathrm{Si}_{3}$ phase reportedly can reach values as high as 21 and 12 at.\% [16], respectively.

The precipitation behavior of $\mathrm{Ti}_{5} \mathrm{Si}_{3}$ during tempering of quenched Ti-2 wt.\% (3.4 at.\%) Si alloy showed that two forms of the silicide are observed [11]. Higher tempering temperatures $(\mathrm{T}>973 \mathrm{~K})$ favor the formation of rods, while lower temperatures (773-873 K) favor formation of an hexagonal plate morphology. The orientation relationships of the rod-like and hexagonal plate $\mathrm{Ti}_{5} \mathrm{Si}_{3}$ with $\alpha$-Ti are $(\overline{1} 2 \overline{1} 1)[1 \overline{2} 16] \mathrm{Ti}_{5} \mathrm{Si}_{3} \|(\overline{1} 2 \overline{1} 0)[0001] \alpha-\mathrm{Ti}$, and (0001)[10 $\left.\overline{1} 0\right] \mathrm{Ti}_{5} \mathrm{Si}_{3} \|(0001)[21 \overline{3} 0]$ $\alpha$-Ti, respectively. However, a different orientation relationship of $\mathrm{D}_{8} \mathrm{Ti}_{5} \mathrm{Si}_{3}$ with $\mathrm{A} 3$ $\alpha$-Ti in binary and $\mathrm{Nb}$-modified $\mathrm{Ti}-\mathrm{Si}$ alloys was observed in the present research, which is $(1 \overline{1} 00)[\overline{1} \overline{1} 26] \mathrm{Ti}_{5} \mathrm{Si}_{3} \|(01 \overline{1})[5 \overline{1} \overline{4} \overline{3}] \alpha-\mathrm{Ti}$. The orientation relationship between $\mathrm{Ti}_{5} \mathrm{Si}_{3}$ and $\alpha$-Ti determined above is analyzed in terms of the coincidence site lattice model [24], i.e., by fitting corresponding lattice planes on both sides of the 
interface. The calculated lattice mismatches with room temperature lattice parameters in two different directions in the $\mathrm{Ti}_{86.5} \mathrm{Si}_{13.5}$ and $\left(\mathrm{Ti}_{86.5} \mathrm{Si}_{13.5}\right)_{97} \mathrm{Nb}_{3}$ alloys are 4.12 and $4.17 \%$, respectively, yielding low lattice strains. This suggests that there is a slight increase in the lattice mismatch due to the addition of $\mathrm{Nb}$.

Typical eutectic structures are rod-like, lamellar, globular, and acicular [25]. Fig. $2 \mathrm{a}$ and $\mathrm{b}$ indicate that the eutectic $\mathrm{Ti}_{86.5} \mathrm{Si}_{13.5}$ alloy shows a rod-like morphology. The rod-like structures present in the eutectic $\mathrm{Ti}_{86.5} \mathrm{Si}_{13.5}$ alloy could be modified by the addition of $\mathrm{Nb}$ to obtain a bimodal structure with micrometer-sized primary $\alpha$-Ti dendrites embedded in the ultrafine matrix $\left(\alpha-\mathrm{Ti}+\mathrm{Ti}_{5} \mathrm{Si}_{3}\right)$ as shown in Fig. 2c. The reduced eutectic rod spacing of $\alpha-\mathrm{Ti}$ and $\mathrm{Ti}_{5} \mathrm{Si}_{3}$ shown in Fig. $2 \mathrm{c}$ and $\mathrm{d}$ in the $\left(\mathrm{Ti}_{86.5} \mathrm{Si}_{13.5}\right)_{97} \mathrm{Nb}_{3}$ alloy results from a decrease of interface energy caused by the addition of $\mathrm{Nb}$. Park et al. reported a reduced lamellar spacing in binary $\mathrm{Fe}-\mathrm{Nb}$ alloys with $\mathrm{Al}$ additions [26]. The precipitation of the primary $\alpha$-Ti dendrites in the $\left(\mathrm{Ti}_{86.5} \mathrm{Si}_{13.5}\right)_{97} \mathrm{Nb}_{3}$ alloy compared with the Ti-Si eutectic results in both increased strength and ductility. The $\left(\mathrm{Ti}_{86.5} \mathrm{Si}_{13.5}\right)_{97} \mathrm{Nb}_{3}$ alloy exhibited a substantially higher plastic strain of $12 \%$ while preserving an ultimate strength of $1180 \mathrm{MPa}$.

The eutectic $\mathrm{Ti}_{70.5} \mathrm{Fe}_{29.5}$ alloy with the addition of 3 at.\% $\mathrm{Nb}$ also shows a bimodal structure with micrometer-sized primary $\beta$-Ti dendrites embedded inside an ultrafine eutectic $(\beta-\mathrm{Ti}+\mathrm{TiFe})$. For the $\left(\mathrm{Ti}_{70.5} \mathrm{Fe}_{29.5}\right)_{97} \mathrm{Nb}_{3}$ alloy. the compression specimen fractured at a plastic strain of $15 \%$ and a strength of $2.53 \mathrm{GPa}$, while for the $\mathrm{Ti}_{70.5} \mathrm{Fe}_{29.5}$ alloy the plastic strain is $7 \%$ and the strength is $2.14 \mathrm{GPa}$ in compression [27]. Similar results have been reported for a $\mathrm{Ti}_{60} \mathrm{Cu}_{14} \mathrm{Ni}_{12} \mathrm{Sn}_{2} \mathrm{Nb}_{10}$ alloy with an insitu formed $\beta$-Ti dendrite/nanostructured matrix microstructure. That alloy had a high compressive strength of $2.4 \mathrm{GPa}$ and $14.5 \%$ plastic strain to failure at room temperature [4]. We believe that the formation of a bimodal structure and the good 
compatibility between the $\alpha-\mathrm{Ti}(\mathrm{A} 3)$ and $\mathrm{Ti}_{5} \mathrm{Si}_{3}\left(\mathrm{D} 8_{8}\right)$ structures are responsible for the improved ductility of the Nb-modified Ti-Si eutectic alloy. The larger lattice mismatch between the $\mathrm{A} 3$ and $\mathrm{D} 8_{8}$ phases in the $\left(\mathrm{Ti}_{86.5} \mathrm{Si}_{13.5}\right)_{97} \mathrm{Nb}_{3}$ alloy due to the addition of $\mathrm{Nb}$ may relieve the dislocation pile-ups by slip transfer across the A3/D8 8 interface $[28,29]$, thereby improving the ductility of the $\left(\mathrm{Ti}_{86.5} \mathrm{Si}_{13.5}\right)_{97} \mathrm{Nb}_{3}$ alloy.

\section{Conclusions}

Nb-modified ultrafine Ti-Si eutectic alloys were fabricated by cold crucible levitation melting, and their mechanical properties were tested in compression at room temperature. Microstructural investigations indicated that the rod-like structure present in the eutectic $\mathrm{Ti}_{86.5} \mathrm{Si}_{13.5}$ alloy could be modified by the addition of $\mathrm{Nb}$ to obtain a bimodal structure with micrometer-sized primary $\alpha$-Ti dendrites embedded in the refined ultrafine eutectic matrix. The enhanced plasticity of the Nb-modified Ti-Si eutectic alloy is attributed to the bimodal structure, reduced ultrafine rod spacing, and the compatibility between the $\alpha-\mathrm{Ti}(\mathrm{A} 3)$ and $\mathrm{Ti}_{5} \mathrm{Si}_{3}\left(\mathrm{D} 8_{8}\right)$ structures. The $\left(\mathrm{Ti}_{86.5} \mathrm{Si}_{13.5}\right)_{97} \mathrm{Nb}_{3}$ alloy exhibited a substantially higher plastic strain (12\%) while preserving high ultimate strength $(1180 \mathrm{MPa})$. The orientation relationship of $\mathrm{D} 8_{8}$ $\mathrm{Ti}_{5} \mathrm{Si}_{3}$ with A3 $\alpha$-Ti is (1 $\left.\overline{1} 00\right)[\overline{1} \overline{1} 26] \mathrm{Ti}_{5} \mathrm{Si}_{3} \|(01 \overline{1})[5 \overline{1} \overline{4} \overline{3}] \alpha$-Ti.

\section{Acknowledgements}

This work was supported by the National Natural Science Foundation of China (NSFC) under Grant no. 51271107, the Innovation Program of Shanghai Municipal Education Commission under Grant no. 13ZZ077, and the Network for Functional Nanostructures funded by the Baden-Württemberg Foundation. The Ames Laboratory is operated for the US Department of Energy by Iowa State University under Contract No. DE-AC02-07CH11358. 


\section{References}

[1] A.M. Russell, K.L. Lee, Structure-Property Relations in Nonferrous Metals, John Wiley \& Sons, NJ, 2005.

[2] C. Leyens, M. Peters, Titanium and Titanium Alloys: Fundamentals and Applications; Wiley VCH Verlag, Weinheim, 2003.

[3] E. Ma, Eight routes to improve the tensile ductility of bulk nanostructured metals and alloys, JOM 58 (2006) 49-53.

[4] G. He, J. Eckert, W. Löser, L. Schultz, Novel Ti-base nanostructure-dendrite composite with enhanced plasticity, Nature Mater. 2 (2003) 33-37.

[5] C.C. Koch, Optimization of strength and ductility in nanocrystalline and ultrafine grained metals, Scr. Mater. 49 (2003) 657-662.

[6] E. Ma, Four approaches to improve the tensile ductility of high-strength nanocrystalline metals, J. Mater. Eng. Perf. 14 (2005) 430-434.

[7] Y.M. Wang, M.W. Chen, F.H. Zhou, E. Ma, High tensile ductility in a nanostructured metal, Nature 419 (2002) 912-915.

[8] L. Lu, Y.F. Shen, X.H. Chen, L.H. Qian, K. Lu, Ultrahigh strength and high electrical conductivity in copper, Science 304 (2004) 422-426.

[9] L. Lu, X. Chen, X. Huang, K. Lu, Revealing the maximum strength in nanotwinned copper, Science 323 (2009) 607-610.

[10] K. Lu, L. Lu, S. Suresh, Strengthening materials by engineering coherent internal boundaries at the nanoscale, Science 324 (2009) 349-352. 
[11] L.S. Chumbley, B.C. Muddle, H.L. Fraser, The crystallography of the precipitation of $\mathrm{Ti}_{5} \mathrm{Si}_{3}$ in Ti-Si alloys, Acta Metall. 36 (1988) 299-310.

[12] R. Yu, L.L. He, J.T. Guo, H.Q. Ye, V. Lupinc, Orientation relationship and interfacial structure between $\zeta-\mathrm{Ti}_{5} \mathrm{Si}_{3}$ precipitates and $\gamma$-TiAl intermetallics, Acta Mater. 48 (2003) 3701-3710.

[13] F. Herrouin, D. Hu, P. Bowen, I.P. Jones, Microstructural changes during creep of a fully lamellar TiAl alloy, Acta Mater. 46 (1998) 4963-4972.

[14] P.B. Celis, K. Ishizaki, Synthesis of intermetallics for high temperature structural applications: $\left(\mathrm{Mn}_{5} \mathrm{Si}_{3}\right) 16 \mathrm{H}$ crystal structure, J. Mater. Sci. 26 (1991) 3497-3502.

[15] C.L. Yeh, W.H. Chen, An experimental investigation on combustion synthesis of transition metal silicides $\mathrm{V}_{5} \mathrm{Si}_{3}, \mathrm{Nb}_{5} \mathrm{Si}_{3}$, and $\mathrm{Ta}_{5} \mathrm{Si}_{3}$, J. Alloys Compd. 439 (2007) 5966.

[16] L. Zhang, J. Wu, $\mathrm{Ti}_{5} \mathrm{Si}_{3}$ and $\mathrm{Ti}_{5} \mathrm{Si}_{3}$-based alloys: alloying behavior, microstructure and mechanical property evaluation, Acta Mater. 46 (1998) 35353546.

[17] Y.X. Yin, H.M. Wang, High-temperature wear behaviors of a laser melted $\mathrm{Cu}_{\mathrm{ss}} /\left(\mathrm{Cr}_{5} \mathrm{Si}_{3}-\mathrm{CrSi}\right)$ metal silicide alloy, Mater. Sci. Eng. A $452-453$ (2007) 746-750.

[18] K. Kishida , M. Fujiwara, H. Adachi, K. Tanaka, H. Inui, Plastic deformation of single crystals of $\mathrm{Ti}_{5} \mathrm{Si}_{3}$ with the hexagonal D8 8 structure, Acta Mater. 58 (2010) 846857.

[19] J. Williams, M. Akinc, Oxidation behavior of $\mathrm{V}_{5} \mathrm{Si}_{3}$ based materials, Intermetallics 6 (1998) 269-275. 
[20] J.H. Schneibel, C.J. Rawn, T.R. Watkins, E.A. Payzant, Thermal expansion anisotropy of ternary molybdenum silicides based on $\mathrm{Mo}_{5} \mathrm{Si}_{3}$, Phys. Rev. B 65 (2002) 134112.

[21] T.B. Massalski, Binary Alloy Phase Diagrams, ASM International, OH, 1990.

[22] PCPDFWIN Version 2.2, JCPDS-International Center for Diffraction Data, 2001.

[23] A.V. Dobromyslov, V.A. Elkin, Martensitic transformation and metastable $\beta$ phase in binary titanium alloys with d-metals of 4-6 periods, Scr. Mater. 44 (2001) 905-910.

[24] K. Subba Rao, R. Tamm, G.H. Cao, C.-G. Oertel, W. Skrotzki, S.C. Wimbush, B. Holzapfel, Microstructure and texture of $\mathrm{YNi}_{2} \mathrm{~B}_{2} \mathrm{C}$ thin films grown on Ir buffered MgO (001), J. Appl. Phys. 100 (2006) 123911.

[25] P. Haasen, Physical Metallurgy, Cambridge University Press, UK, 1996.

[26] J.M. Park, K.B. Kim, W.T. Kim, M.H. Lee, J. Eckert, D.H. Kim, High strength ultrafine eutectic $\mathrm{Fe}-\mathrm{Nb}$ - $\mathrm{Al}$ composites with enhanced plasticity, Intermetallics 16 (2008) 642-650.

[27] G.H. Cao, Y.F. Peng, N.Liu, X. Li, Z.S. Lei, Z.M. Ren, D. Gerthsen, A.M. Russell, Formation of a bimodal structure in ultrafine Ti-Fe-Nb alloys with highstrength and enhanced ductility, Mater. Sci. Eng. A 609 (2014) 60-64.

[28] A. Misra, R.Gibala, High strength ultrafine eutectic Fe-Nb-Al composites with enhanced plasticity, Intermetallics 8 (2000) 1025-1034.

[29] J. Das, K.B. Kim, F. Baier, W. Löser, J. Eckert, High-strength Ti-base ultrafine eutectic with enhanced ductility, Appl. Phys. Lett. 87 (2005) 16190. 